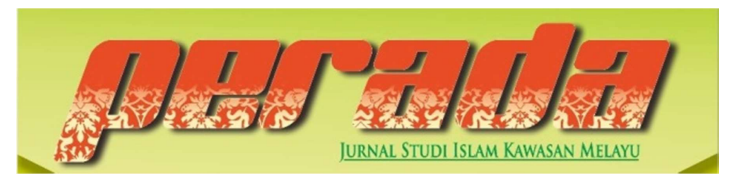

Perada: Jurnal Studi Islam Kawasan Melayu

ISSN 2656-7202 (P) ISSN 2655-6626 (E)

Volume 2 Nomor 2, Juni-Desember 2019

DOI: $10.35961 /$ perada.v2i2.36

\title{
MODEL TAHAQQUH DALAM TAZKIYAH AL-NAFS OLEH SAID HAWWA BAGI MERAWAT JIWA MUSLIM
}

\author{
Nur Zainatul Nadra Zainol \\ Institut Ahli Sunnah wal Jamaah, Universiti Tun Hussein Onn Malaysia Johor. \\ nadra@uthm.edu.my \\ Dayangku Zainab binti Pengiran Haji Tuah \\ Universiti Perguruan Ugama Seri Begawan, Brunei Darussalam \\ zainab.tuah@kupu-sb.edu.bn
}

\begin{abstract}
ABSTRAK
Tazkiyah al-nafs ialah suatu kaedah pendidikan jiwa seseorang manusia yang berbentuk penyucian dalaman dan pembentukan luaran supaya dapat mengekang kemahuan dan sifat buruk yang membawa kepada ketidaksihatan mental dan kecelaruan tingkah laku. Tokoh-tokoh tasawuf telah memperkenalkan kaedah dalam penyucian jiwa antaranya Syeikh Sa'id Hawwa yang memperjelaskan lagi kaedah Imam al-Ghazali dalam penyucian jiwa. Artikel ini bertujuan untuk menganalisis pendekatan tahaqquq yang diketengahkan oleh Syeikh Sa'id Hawwa dalam kaedah tazkiyah al-nafs. Kajian ini adalah kajian kualitatif dengan reka bentuk analisis kandungan. Hasil kajian menunjukkan Sheikh Said Hawwa telah mengetengahkan proses dan peringkat tahaqquq dalam kaedah tazkiyah al-nafs yang berupaya mendidik jiwa manusia supaya terhindar daripada ketidaksihatan mental dan kecelaruan jiwa dengan sifat-sifat mazmumah. Kajian ini dapat menjelaskan model komprehensif tahaqquq dalam kaedah penyucian jiwa berlandaskan al-Quran dan al-sunnah.
\end{abstract}

Kata kunci: Penyucian jiwa; kaedah Islam; Tasawuf.

\section{Abstract}

Tazkiyah al-nafs is a method for purification of the human soul. The purification occurred in the form of internal purification and external formation in order to suppress desires and bad habits that lead to mental health and behavioral disorders. Sufism figures have introduced the method of purification of the soul, including Sheikh Sa'id Hawwa, which further explains Imam alGhazali's method of purification of the soul. This article aims to analyze the tahaqquq approach introduced by Sheikh Sa'id Hawwa in the method of tazkiyah al-nafs. This study is a qualitative study with content analysis design. The results show that Sheikh Said Hawwa emphasized the process and level of tahaqquq in the method of tazkiyah al-nafs which is able to educate the human soul to avoid mental health and mental disorders with the properties of the mosque. This 
study explains the comprehensive model of tahaqquq in the method of purification of the soul based on the Quran and al-sunnah.

Keywords: Penyucian jïwa; kaedah Islam; ilmu Tasawuf; Tokob Islam.

\section{PENDAHULUAN}

Tazkiyah al-Nafs adalah bentuk penyucian rohani dan peribadi daripada perkara-perkara yang keji kepada memartabatkan akhlak-akhlak mulia sebagaimana yang dimiliki insan kamil, nabu Muhammad SAW. Bentuk penyucian rohani ini perlu dilalui dengan pelbagai martabat-martabat dan peningkatan agar dua proses pembersihan dapat dilakukan, iaitu proses mujahadah memerangi hawa nafsu dan mengeluarkan diri daripada akhlak-akhlak tercela yang dinamakan takhalli, kemudian prosesproses membina akhlak-akhlak dan peribadi unggul di dalam diri yang dinamakan tahalli. ${ }^{1}$

Justeru Tazkiyah al-Nafs ini berhubung dengan akhlak dan kejiwaan dalam membentuk pola pembentukan manusia yang bertakwa serta berakhlak mulia kerana sesiapa yang mengharapkan pertemuan dengan Allah SW'T mesti mahu memperelokkan akhlak dan membersihkan jiwa kerana tazkiyah alNafs adalah sebagai lambang kebahagiaan seorang hamba. ${ }^{2}$ Proses-proses tazkiyah al-Nafs utama yang akan dijalani adalah ibadah solat, puasa, tafakkur, qiyam al-lail dan berzikir. Pelaksanaan demi pelaksanaan yang dilakukan dan tingkatan demi tingkatan yang dilalui akan mendatangkan kesan positif ke atas

${ }^{1}$ Zidni Nuran Noordin and Zaizul Ab. Rahman, 'Perbandingan Proses Tazkiyah Al-Nafs Menurut Imam al-Ghazali Dan Ibnu Qayyim', Jurnal Al-Turath, 02.01 (2017), 37-46.

${ }^{2}$ Moh Zaman, 'Konsep Tazkiyat Al-Nafs Dalam Al-Qur'an: Perspektif Ahmad Mustofa AlMaraghi Dalam Tafsir Al-Maraghi, Dan Signifikansinya Terhadap Pendidikan Karakter Di Indonesia' (Universitas Islam Negeri Maulana Malik Ibrahim, 2016). peribadi seseorang dan memberikan pemulihan kepada jiwa. ${ }^{3}$

\section{BIODATA SAID HAWWA}

Nama lengkap Said Hawwa adalah Said bin Muhammad bin Dib Hawwa. Beliau berasal daripada Hamah, Suria yang lahir pada tahun $1935 \mathrm{M}^{4}$ Ibunya bernama Arabiyah al-Thaisy, meninggal ketika usianya memasuki dua tahun lalu beliau diasuh oleh neneknya. Beliau dipanggil sebagai Abu Muhammad. ${ }^{5}$ Ayah Said Hawa kemudiannya menikah lagi dan beliau berada di bawah bimbingan ayahnya yang merupakan seorang yang berpengaruh dalam masyarakat. Ayah Said Hawwa adalah seorang pejuang ketika jajahan Perancis, Said Hawwa pula membesar dengan pemikiran-pemikiran sosialis, nasionalis, Ba'tsi serta Ikhwanul Muslimin. ${ }^{6}$

Pendidikan Said Hawwa penuh dengan kesusahan. Beliau bekerja keras untuk mendapatkan pendidikan yang baik di samping mencukupi keperluan hidup namun beliau tetap meneruskan pendidikannya sehingga beliau memperoleh Sijil Tinggi dalam Agama. Said Hawwa juga pernah menyertai ketenteraan namun tidak lama kemudian mengundurkan diri kerana tidak merasa sesuai di dalam kursus ketenteraan

\footnotetext{
3 Abu Dardaa Mohamad, Salasiah Hanin Hamjah, and Ahmad Irdha Mokhtar, 'Konsep Tazkiyah al-Nafs Menurut al-Harith bin Asad alMuhasibi', 4 (2017), 11.

${ }^{4}$ Ryan Alfian, 'Konsep Kepemimpinan Menurut Sa'îd Hawwa Dalam Kitab Al-Asâs Fî al-Tafsîr Dan al-Islâm’, 2014.

${ }^{5}$ Dedi Suriansah, 'Pemikiran Sa'id Hawwa Tentang Jiwa (Studi Analisis Perjalanan Jiwa Menuju Allah)', 2012.

'Said Hawwa, Al-Mustakhlas Fi Tazkiyah alAnfus (Dar al-Salam: Robbani Press, 1996).
} 
tersebut. Kemudian beliau mendaftarkan diri di Universiti Syariah di Damaskus Syria pada tahun 1956 yang mana di dalam kuliah-kuliah pelajarannya, beliau tertarik dengan kuliah yang disampaikan oleh Dr Musthafa al-Siba'ie yang ketika itu menjadi ketua umum Ikhwanul Muslimin di Syria. Berkat kesungguhan beliau, ketika pengajian di universiti itu beliau sempat menghabiskan 30 juzuk alQuran pada tahun pertama pengajian. ${ }^{7}$

Kemudian corak-corak kehidupannya itu menjadikan Said Hawwa seorang yang berperibadi teguh di dalam Islam, beliau menjadi pemimpin suatu gerakan Islam Ikhwanul Muslimin dan juga sebagai pendidik umah pada zamannya. Penglibatan beliau di dalam pendidikan dan dakwah sekaligus menjadikan beliau seorang tokoh yang berpengaruh. Beliau berhasil mencetuskan idea-idea baru dalam menhuraikan isu-isu perkembangan Islam. $^{8}$

\section{PENGENALAN KEPADA KITAB AL-MUSTAKHLAS FI TAZKIYAH AL-ANFUS}

Kitab ini adalah sebuah kitab ringkasan daripada tulisan Imam Imam Al-Ghazali yang terdapat di dalam kitab Ihya' Ulumuddin dan dimuatkan oleh Sa'id Hawwa sebagai ringkasan proses Tazkiyah Al-Nafs, kerana itu ia dinamakan sebagai Al-Mustakblas Fi Tarkiyah Al-Anfus atau diterjemahkan sebagai "Ringkasan dalam proses Penyucian Jiwa".

Ringkasan Tazkiyah Al-Nafs yang dipilih oleh Sa'id Hawa di dalam kitab ini mengandungi empat bab. Bab pertama adalah berkaitan Adab Guru dan Murid. Bab kedua menjelaskan tentang Wasail

\footnotetext{
${ }^{7}$ Suriansah.

${ }^{8}$ Mawaddah Baderun and Haziyah Hussin, 'Sheikh Sa'id Hawwa: Latar Belakang \& Ketokohan Di Dalam Bidang Pendidikan Islam', Al-Hikmah, 8.1 (2016), 19-35.
}

Tazkiyah yang berupa berbagai ibadah dan amal perbuatan. Bab ini mempunyai tiga poin penting beserta huraian. Bab ketiga adalah berkenaan Hakikat Tazkiyah Al-Nafs dan bab ini juga mempunyai tiga poin penting beserta huraian yang panjang. Manakala bab keempat pula adalah sebagai hasil daripada penyucian jiwa tersebut. Keutamaan hasil dapat dilihat kepada lidah dalam mengendalikan hubungan dan adab-adab yang dijalankan bagi menjaga lidah.

\section{DEFINISI DAN PENGERTIAN TAZKIYAH AL-NAFS}

Penyucian (al-Tazkiyah) dalam Bahasa Arab berasal daripada perkataan zaka' yang bermaksud suci. Al-Tazkiyah bermaksud tumbuh, suci dan berkat. Zakat dimaksudkan dengan dua pengmaksudan iaitu menyucikan harta dan menyucikan jiwa.' Terdapat enam ayat al-Quran tentang kalimah zaka di dalam konteks makna yang hamper serupa tetapi tidak sama tetapi berkait. ${ }^{10}$

Pengmaksudan al-Nafs dari segi bahasa dan Istilah pula dapat dikembangkan kepada pelbagai pengmaksudan yang luas. Dalam ruang lingkup ini dapat dinyatakan al-nafs mempunyai dua makna utama iaitu ruh ataupun juga bermaksud sesuatu atau hakikat. Al-nafs menurut Imam Ghazali adalah pengmaksudan yang meliputi sifat marah dan hawa nafsu yang ada dalam siri manusia menjadi punca timbulnya sifat kecelaan dalam diri manusia, yang keduanya bermaksud hakikat diri serta zat sebenar diri manusia. Ia dapat disimpulkan al-nafs adalah jirim halus yang bergerak memberi kekuatan kepada kehidupan, perasaan dan kehendak

${ }^{9}$ Nor Azlinah Zaini and Che Zarrina Sa'ari, 'Terapi Spiritual Melalui Kaedah Tazkiyah al-Nafs oleh Syeikh Abdul Qadir al-Mandili dalam Kitab Penawar Bagi Hati', Jurnal Akidah \& Pemikiran Islam, 2016, 35-72 <https://doi.org/10.22452/afkar.sp2016no1.2>. ${ }^{10}$ Ibid. 
manusia ataupun sesuatu yang terdapat di dalam diri manusia yang tidak diketahui kewujudannya, yang dapat menerima kebaikan dan keburukan, memiliki pengaruh yang nyata kepada perilaku manusia, ia mencakupi hati dan roh. ${ }^{11}$

Penyucian jiwa adalah termasuk daripada misi dibangkitkan nabi-nabi dan rasul. Penyucian jiwa adalah suatu matlamat orang-orang bertakwa dan ianya termasuk perkara yang menjadi ketentuan bagi kedudukan setiap manusia di sisi Allah di akhirat. Taziyah secara etimologi mempunyai dua makna iaitu penyucian dan pertumbuhan. Demikian pula secara istilah. Zakatun nafsi bermaksud penyucian jiwa daripada segala penyakit dan cacat, merealisasikan tahaqquq dan menjadikan asma' dan sifat sebagai akhlaknya. Tazkiyah juga bermaksud tathabhur, tahaqquq dan takballuq. ${ }^{12}$

Tazkiyah al-nafs menempati posisi yang paling penting di dalam tasawuf dan menjadi satu agenda terpenting sufi sama ada sufi klasik atau kontemporer. Imam Al-Ghazali misalnya, seorang ulama yang berkarisma telah banyak mengkaji tarkiyah al-nafs dalam beberapa buku tasawufnya yang merangkumi kaedah penyucian jiwa melalui proses takhalli (menghilangkan sifat-sifat tercela) seiring mengisinya dengan tahalli (sifat-sifat terpuji). Tazkiyah al-nafs juga bermaksud penyucian jiwa daripada sifat-sifat kebinatangan dan sifat-sifat syaitan kemudiannya diisi dengan akhlak ketuhanan (rabbaniyyah). Tazkiyah alnafs berhubungan dengan pelbagai aspek iaitu akhlak, kejiwaan, dan usaha mendekati Allah SWT kerana Allah Maha suci, dan ia hanya boleh didekati dengan jiwa yang suci. Tazkiyah al-Nafs merupakan proses penjernihan atau pembeningan hati agar tembus cahaya daripada Allah SWT. Pandangan ini didasari pula dengan argumentasi hati

\footnotetext{
${ }^{11}$ Ibid.

${ }^{12}$ Hawwa, Al-Mustakblas.
}

manusia sepmaksud kaca sedangkan dosa adalah noda yang akan mengotorkan kebeningan kaca. Justeru, tazkiyah al-nafs adalah proses penyucian batin manusia dan proses menghilangkan sifat-sifat kotor manusia yang merintangi jiwa dalam berhubung dengan Allah. ${ }^{13}$

\section{ANALISIS KAEDAH TAHAQQUQ DALAM TAZKIYAH AL-NAFS OLEH SAID HAWWA}

Proses untuk melaksanakan kaedah Tahaqquq dalam Tazkiyah al-Nafs perlu melalui kaedah pertama iaitu menjaga kesempurnaan dalam ibadah asas. Kemudian diikuti oleh kaedah kedua iaitu proses tahaqquq. Perincian kaedah dalam tazkiyah al-nafs adalah seperti berikut:

\section{Kaedah Pertama: Penerapan Sempurna pada Aspek Ibadah Asas} Kaedah yang pertama adalah melalui penerapan kesempurnaan ibadah asas. Ibadah asas terdiri daripada solat, zakat dan infak, puasa, haji, membaca alquran, zikir, tafakkur. Tujuan kaedah pertama adalah untuk mencapai:

a) Penerapan rohani asas pertama: muraqabah, muhasabah, mujahadah dan mu'aqabah, amar makruf nahi munkar dan jihad

b) Penerapan Rohani Asas Kedua: berkhidmat dan tawaduk, mengetahui dan menutup pintu syaitan, mengenal penyakit hati, penyembuhan dan kesihatannya.

\section{Kaedah Kedua: Penyucian Jiwa}

Kepentingan kaedah kedua adalah untuk menyucikan diri daripada segala jenis penyakit jiwa, iaitu menyucikan diri dari pelbagai penyakit, tahaqquq (tauhid, ikhlas, siddiq, zuhud, tawakkal, mahabbatullah, khawf dan raja', takwa dan wara', syukur, sabar dan redha, muraqabah dan musyahadah). Perincian

\footnotetext{
${ }^{13}$ Azyumardi Azra, 'Ensiklopedi Tasawuf, Bandung: Angkasa, 2008.
} 
kaedah tahaqquq adalah seperti berikut:

\section{a) Taubid dan Ubudiyah (Penghambaan)}

Akar segala maqam adalah maqam ubudiyah, iaitu bersumberkan tauhid kepada Allah SWT. Daripada maqam inilah munculnya maqam-maqam yang selanjutnya sepmaksud ikhlas, tawakal, takut, harap, cinta dan takwa.

Keutamaan maqam ubudiyyah dapatlah dilihat pada perutusan rasulrasul sebagai wakil tuhan kepada manusia. Allah mengutuskan sekalian rasul tidaklah selain menyampaikan wahyu ilahi kepada manusia bagi tujuan ubudiyah dan tauhid kepada Allah. Tujuan ubudiyah ini berlanjutan daripada satu zaman kepada zaman selanjutnya dengan perutusan satu rasul kepada rasul yang selanjutnya. Rasul juga membawa risalah dan sebagai tajdid kepada syariat Allah SW'T sehinggalah kepada zaman baginda Rasulullah SAW yang al-Quran sebagai risalah akhir yang mana tidak lagi menjadi keperluan bagi mengutuskan nabi atau rasul.

Seseorang yang telah menerapkan sifat ubudiyah di dalam diri akan menjadi rabbaniyyin yang akan mencapai maqam yang tinggi di sisi Allah sebagaimana pengiktirafan yang disebutkan Allah kepada nabi Muhammad SAW ketika malam Isra' :

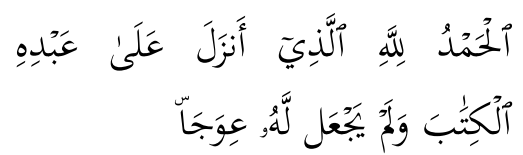

Artinya: "Segala puji terentu bagi Allah yang telab menurunkan kepada hambaNya (Mubammad), Kitab suci Al-Quran, dan tidak menjadikan padanya sesuatu yang bengkoke (terpesong)"

Ubudiyah adalah dengan mengenal (makrifah) hakikat sifat Allah dan beribadah kepadanya. Ahli suluk (orang soleh) sepakat mengatakan tauhid kepada Allah adalah tujuan awal dan akhir, manakala setiap peningkatan ibadah diperoleh dari ketauhidan kepada Allah di dalam hati. Kesempurnaan tauhid dicapai dengan fana pada perbuatan, fana pada sifat, fana dalam hukum serta fana dalam komitmen dan amal. Fana dalam perbuatan didapati apabila hati merasakan sesuatu yang berlaku merupakan perbuatan Allah, fana dalam sifat apabila merasakan diri sendiri tiada daya kecuali daripada kekuatan Allah, fana dalam hukum apabila hati tunduk kepada hukum Allah serta fana dalam amal adalah dengan mengerahkan tenaga untuk beribadah kepada Allah SWT serta melaksanakan amalan-amalan sunat sepmaksud zikir, solat, puasa membaca al-Quran, istighfar, selawat dan amalan yang mendekatkan diri kepada Allah. ${ }^{14}$

\section{b) Ikblas}

Ikhlas bermaksud bersih atau terhindar daripada noda dan dosa, dapat difahami daripada maksudan makna ayat al-Quran bahawa ikhlas itu murni, sebagaimana firman Allah SWT dalam surah al-Nahl ayat 66 yang artinya, "(berupa susu) yang bersib Antara tabi dan darah yang mudah ditelan bagi orang-orang yang meminumnya."

Justeru ikhlas adalah sesuatu yang murni dan suci, tidak dicampur dengan sesuatu. Lawan bagi sifat Ikhlas adalah syirik, namun perbezaannya hanyalah pada tingkatan syirik. Tempat bagi Ikhlas adalah di dalam hati iaitu berkaitan dengan tujuan dan niat seseorang. Jika faktor yang membangkitkannya satu, perbuatan itu ikhlas, tiada niat lain berupa menunjuk-nunjuk dan sebagainya, ia hanya ditujukan kepada matlamatnya sahaja, ikhlas juga boleh difahami dengan melaksanakan sesuatu kerana mencari redha Allah.

Namun menjadi persoalan apabila seseorang yang melaksanakan ibadah untuk taqarrub kepada Allah namun mereka juga mempunyai niat yang lain sepmaksud puasa untuk mendekatkan diri

${ }^{14}$ Said Hawwa, Al-Mustakblas Fi Tazkiyah al-Anfus, h. 341-44. 
dan mendapatkan manfaat kesihatan, mempelajari ilmu untuk memudahkan memperoleh harta, menjadi wibawa dan sebagainya. Justeru pekara tersebut juga ternoda dengan keinginannya, kecuali apabila seseorang itu dalam tujuan yang disertakan itu akan membawa ia mendekati Allah juga maka itu tidak merosakkan keikhlasannya. Sebagai contoh berpuasa untuk taqarrub dan sihat supaya mudah beribadah kepada Allah, justeru perkara itu menjadi penguatnya dalam mengamalkan kebaikan dan pahala tersebut juga bertambah dengan niat yang baik tersebut.

Justeru, yang menjadi perhatian adalah saat taqarrub kepada Allah haruslah perhatikan niat yang ditujukan adalah menuju redha Allah ataupun tidak kerana Ikhlas menjadi pokok pangkal kesuburan amalan diterima, ditolak dan bertambah atau berkurang, firman Allah:

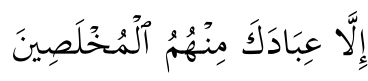

Artinya: "....Kecuali di antara zuriat-zuriat Adam itu hamba-hambaMu yang dibersibkan dari sebarang syirik".

\section{c) Siddiq}

Siddiq adalah jujur kepada Allah, seseorang yang jujur lisan dan amalnya kepada Allah. Ibn Abbas berkata yang maksudnya sesiapa yang memiliki kejujuran maka ia beruntung. Basyar bin harith mengatakan, "sesiapa yang beribadah dengan jujur maka ia tidak akan menjadi penjilat manusia." Makna bagi memahami sifat siddiq ini dapat difahami apabila seseorang mengucapkan keimanannya kepada Allah, ia terbukti dengan amal-amal yang dikerjakan. Mereka jujur dengan ucapan, perbuatan, azam dan dikotakan dengan kesungguhannya. Allah berfirman :

Artinya:"... Orang-orang mukmin itu ada orang-orang yang menepati apa yang mereka janjikan kepada Allah." (Al-Ahzab:23)
Justeru seseorang yang perbuatannya tidak sesuai dengan kata hatinya dengan penuh kesedaran dan sengaja ia disebut riak dan tidak sampai kepada ikhlas dan apabila tidak sengaja, ia tidak sampai kepada siddiq. Definisi siddiq juga dapat dilihat jelas pada surah al-Baqarah : 177

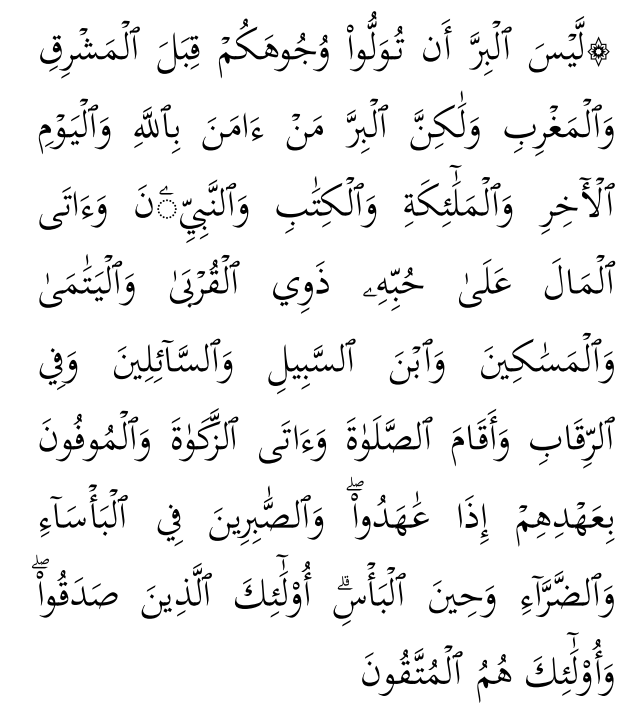

Artinya: "Bukanlab kebaikan itu banya menghadapkan muka ke timur dan barat, tetapi kebajikan itu adalah berimannya seseorang kepada Allah, dan hari akbirat, dan segala malaikat dan segala kitab, dan sekalian nabi dan ia mendermakan harta yang disayangi kepada kaum kerabat, anak-anak yatim dan orang miskin, orang yang terlantar dalam perjalanan, kepada yang meminta dan untuk memerdekakan hamba-bamba abdi, ia mengerjakan solat serta mengeluarkan zakat, ia menyempurnakan janjinya apabila membuat perjanjian dan tabah apabila kesempitan, kesakitan dan dalam peperangan. Merekalah orang-orang yang benar dan mereka orang yang bertakwa."

Dapatlah difahami mereka bersifat jujur dalam segenap aspek kehidupan, bukan pada aspek pilihannya sahaja.

d) Zubud

Sifat zuhud bukan bermaksud seseorang yang meninggalkan harta dan 
hidup terpuruk dengan tidak makan kecuali sedikit sahaja, sifat zuhud yang sebenar mempunyai tiga ciri iaitu Pertama, mereka tidak senang apabila memiliki sesuatu dan tidak bersedih ketika kehilangan sesuatu. Kedua, menganggap celaan dan pujian itu sama. Ketiga, hatinya dipenuhi cinta kepada Allah.

\section{e) Tawakkal}

Maqam tawakal terdiri daripada ilmu, hal dan amal. Hal adalah menerapkan tawakkal dalam diri, ilmu pula dasar daripada tawakkal, amal adalah hasil daripada tawakkal. Definisi ulama tentang tawakkal terlalu banyak namun di sini Said Hawwa menukilkan ringkasan makna daripada apa yang diperbahaskan para ulama.

Tawakkal diambil daripada kata wakalah (perwakilan). Apabila seseorang mewakilkan urusannya kepada seseorang, maksudnya ia menyerahkan semua urusan kepada orang tersebut dengan sepenuh kepercayaan tanpa sebarang keraguan, ataupun menyandarkan dirinya hanya kepada yang diwakilkan. Namun yang menjadi perbezaan adalah tingkat kepercayaan seseorang kepada wakilnya itu, semakin ia mempercayai wakilnya, semakin tinggi kepercayaan untuk menyerahkan urusannya kepada wakilnya, semakin tenang perasaannya, tanpa kerisauan.

Gambaran tersebut memberi maksud begitulah juga apabila seseorang menyerahkan urusan diri kepada Allah. Apabila meyakini tidak ada yang melakukan sesuatu kecuali Allah dan meyakini akan kemampuan Allah adalah memberikan kasih sayang, kecukupan serta meyakini tidak ada kekuatan lain sebanding Allah, itulah saat seseorang menyerahkan segala-galanya kepada Allah, hati, urusan dan sandaran semua dipercayakan kepada Allah. Akan tetapi apabila seseorang tidak lagi meyakini dan menyerahkan segala urusan kepada Allah, dengan rasa bimbang dan tidak tentu, itu melambangkan lemahnya keyakinan kepada Allah dan lemah hatinya kerana bimbang dan risau.

\section{f) Mababbatullab (Cinta Kepada Allah)}

Seharusnya kecintaan adalah kepada Allah SWT dan kepada sesuatu yang berkaitan dengan Allah SWT, seperti utusan Allah SWT, seseorang yang mencintai Allah SWT dan apa jua yang menjadi kecintaan Allah. Seseorang yang basirah (pandangan benar) tidak memberikan cinta murahan dan mengagungkan cinta-cinta bawahan. Bahkan cinta sejati itu terarah kepada Allah SWT kerana sememangnya Allah SWT tempat yang paling layak untuk dicintai melebihi sesuatu. Penjelasan ini terbahagi kepada empat bahagian :

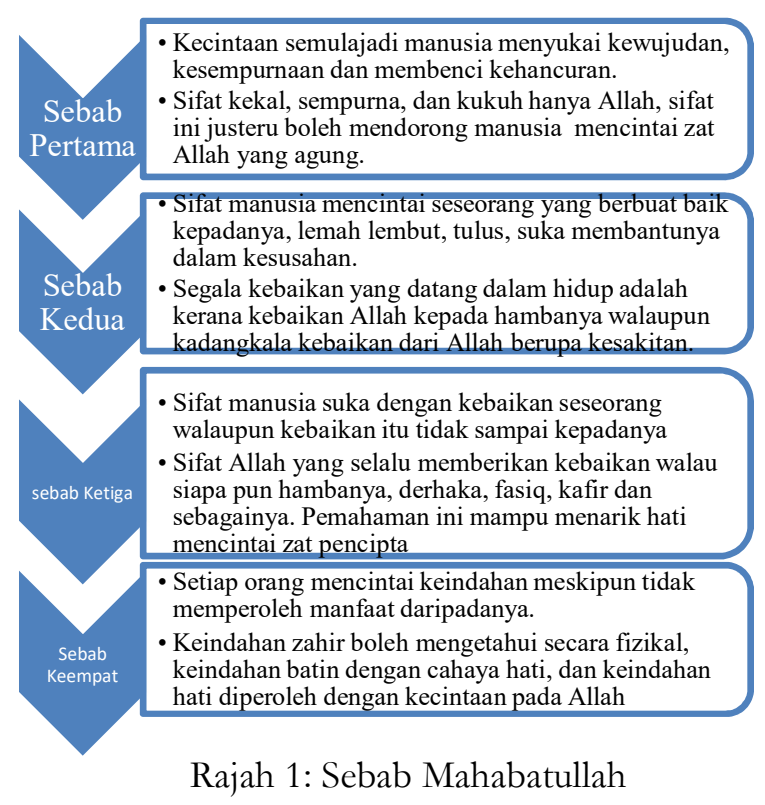

Sebab keempat itu dapat diringkaskan dengan kecintaan yang bermuara dengan hati walaupun fizikal, paras wajah tidak indah. Sepmaksud mencintai ulama, para sahabat, wali-wali dan orang-orang soleh. Keindahan itu diperoleh daripada pengetahuan tentang Allah (makrifah). Sebuah hadis yang 
sesuai bagi memahami kecintaan dan memahami keindahan ini:

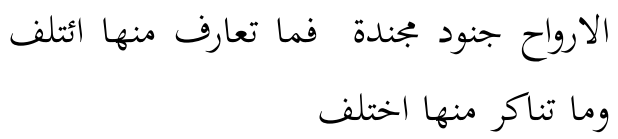

Maksudnya, roh-roh itu adalah tentera yang dimobilisasi, yang saling mengenal akan menyatu, dan tidak mengenal akan berpisah. Kerana itu, mencintai seseorang atau orang-orang soleh yang mengenal Allah akan saling mempertautkan hati kita kepada Allah. Hubungan hati yang mengenal ini hanya dikenali dengan hati yang melihat keindahan dengan ilmu Allah. ${ }^{15}$

\section{g) Takut (khauf) dan Penub Pengharapan (Raja').}

Menurut Imam Ghazali, Khawf dan Raja' merupakan dua sayap yang membawa menembusi jalan akhirat. Harapan tanpa rasa takut menjadikan seseorang itu memaksa Tuhan, rasa takut tanpa pengharapan membawa seseorang putus asa dengan dosa. Tidak ada yang dapat membawa kepada Tuhan kecuali dengan pengaharapan dan tidak ada yang dapat menyelamatkan manusia daripada azab kecuali dengan rasa takut kepada Allah.

Khawf dan Raja' hakikatnya adalah satu maqam yang ditempuhi oleh para pencari jalan Allah, namun jika sifat ini tidak tetap di dalam hati manusia ia disebut haal (keadaan), jika ia tetap berada dalam diri manusia ia dinamakan maqam. Raja' juga adalah ketenangan bagi hati ketika menunggu sesuatu yang disenangi daripada Allah SWT berdasarkan sebabsebab daripada usaha yang dilaksanakan, namun jika berharap dengan sebab-sebab yang tidak jelas, ia dinamakan anganangan (tamanni).

Dengan sebab itu, seorang hamba yang bersungguh-sungguh mentaati Allah

\footnotetext{
15 Ibid, h. 358-364
}

dan menjauhi maksiat berhak menanamkan pengharapan agar mendapat kenimkatan yang sempurna daripada Allah berupa syurga. Begitu juga, ahli maksiat yang bertaubat dengan meninggalkan semua kemaksiatan dan kelalaian juga berhak untuk berharap akan diterima taubatnya.

Khawf dan raja' juga adalah ubat yang seimbang bagi penyakit hati dan keutamaan antara keduanya berubah mengikut keadaan hati, apabila keadaan hati tenang kepada azab Allah lebih menonjol maka khawf lebih baik daripada raja' namun jika putus asa lebih menonjol maka raja' lebih baik.

Seseorang itu juga tidak mungkin boleh aman daripada takut daripada terkena azab Allah berdasarkan sebuah hadis :

$$
\begin{aligned}
& \text { إن الرجل ليعمل عمل أهل الجنة خمسين } \\
& \text { سنة حتى لا يبقى بينه وبين الجنة إلا شبرا } \\
& \text { (وفي رواية : إلا قدر فواق ناقة) فيسبق عليه } \\
& \text { الكتاب فيختم له بعمل أهل النار. }
\end{aligned}
$$

Artinya: "Sesunggubnya ada seorang yang melakukan perbuatan abli syurga selama lima pulub tabun, sebingga tidak ada jarak antara dia dengan syurga kecuali satu jengkal saja (dalam riwayat lain sejarak berdirinya unta) akan tetapi (sebelum masuk ke dalam syurga) datang catatan (pernyataan) bahawa perbuatannya merupakan perbuatan abli neraka."

Hadis ini mengajar kepada kita kepentingan khawf dan raja' sehingga kedua-dua sifat ini perlu seimbang kepada manusia. Apabila raja' mendominasi hati, perkara tersebut merupakan gambaran keterpedayaan dan sedikit pengetahuan. Bagaimana Keadaan Para Nabi, Wali dan Malaikat ketika Takut kepada Allab? Rasulullah SAW pada suatu ketika terjadi perubahan cuaca dan hembusan angin, maka berubah paras wajahnya, ia lalu bangun dan mundar mandir di bilik, 
keluar bilik dan masuk semula berkalikali. Keadaan tersebut menunjukkan Rasulullah SAW takut kepada azab Allah. Rasulullah juga pernah melihat malaikat Jibril dengan rupanya yang asli di lembah sungai dan baginda terus pengsan. Rasulullah juga pernah diriwayatkan melakukan solat namun di dadanya terdengar suara gelegak air mendidih.

$$
\text { جا لي لا أرى أرى ميكائيل يضحك، فقال }
$$

Artinya: "Aku tidak pernab melibat Mikail tersenyum, Jibril berkata, "Mikail tidak pernab tersenyum sejak diciptakan neraka."

\section{b) Sabar, Taslim dan Redha.}

Jika dijelaskan tentang sabar, penjelasannya lebih mudah difahami dengan pengalaman yang dilalui daripada teori yang diajarkan kerana akhirnya sabar yang sebenar ketika seseorang mampu meraihnya dengan sempurna di dalam dirinya sendiri, namun sabar itu dapat difahami dengan terperinci di dalam penjelasan ini.

Dalam memahami maksudan sabar, syukur adalah kaitannya kerana tidak akan bisa seseorang itu bersabar jika tiada sifat syukur. Syukur menuntut kesabaran. Kesabaran terbahagi kepada tiga jenis. Pertama, sabar dalam ketaatan kepada Allah, kedua sabar dari kemaksiatan. Ketiga, sabar mendapat cubaan. Lawan kepada sifat sabar pula adalah keluh kesah. Justeru, di samping sifat sabar, sifat yang akan sama-sama menuntuti manusia dalam ujian kehidupan adalah taslim (berserah diri) dan redha kepada takdir (qadak).

Sabar meninggikan darjat dan kedudukan seseorang di dunia mahupun di akhirat. Sebagai contoh, firman Allah SW'T menyebutkan di dalam surah alSajdah, ayat 24 :

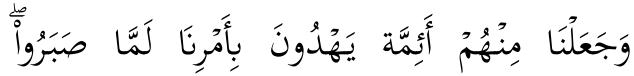 وَكَانُواُ بِايْتَنَا يُوِقِنُونَ} ayat 96 :

Selanjutnya dalam surah al-Nahl

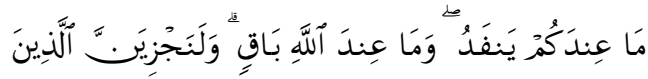

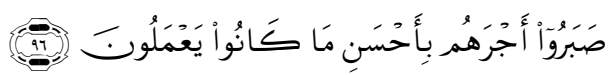

Maksudnya: "Dan sesunggubnya Kami akan memberi balasan kepada orang-orang yang sabar dengan pabala yang lebih baik dari apa yang telah mereka kerjakan." ayat 157 :

Kemudian dalam surah al-Baqarah

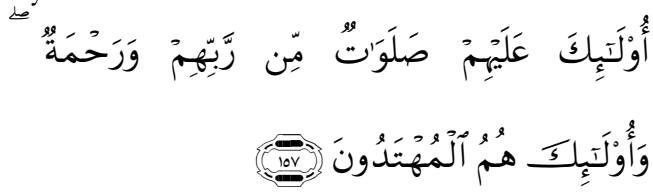

Maksudnya: "Mereka itulab yang mendapatkan keberkatan yang sempurna dan rabmat dari tubannya, dan mereka itulah orang-orang yang mendapat petunjuk."

Adapun Redha bermaksud suka atau pun lapang jiwa menghadapi ujian Allah. Keutamaan Redha pula dapat dilihat berdasarkan firman Allah SWT :

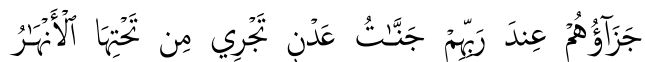

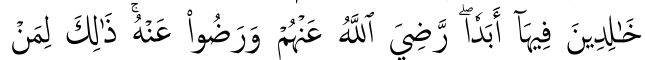
خَثِيَيَ رَبََُّّ،

Artinya: "Balasan mereka di sisi Tuban mereka adalah syurga And (tempat tinggal yang tetap), yang mengalir di bawahnya sungaisungai, kekallah mereka di dalamnya selamalamanya. Allah redha akan mereka dan mereka pun redha akan nikmat pemberianNya."

Allah meletakkan kemuliaan redha lebih tinggi daripada syurgaNya sebaiamana memuliakan zikir mengingati 
Allah daripada solat sebagaimana firman Allah di dalam surah al-Ankabut: 45:

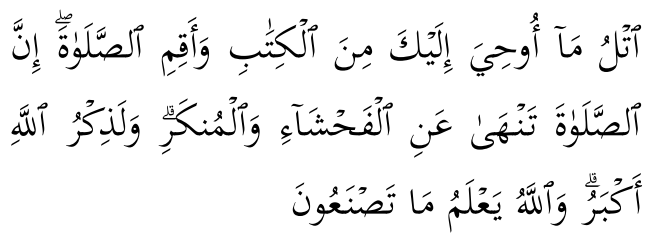

Artinya: "Bacalah serta ikutlah (wabai Mubammad) akan apa yang diwahyukan kepadamu dari Al-Quran, dan dirikanlah sembahyang (dengan tekun); sesunggubnya sembahyang itu mencegah dari perbuatan yang keji dan mungkar; dan sesunggubnya mengingati Allab adalah lebih besar (faedahnya dan kesannya); dan (ingatlab) Allah mengetabui akan apa yang kamu kerjakan."

Kecintaan kepada Allah akan melahirkan sifat redha kerana dengan kecintaan yang kuat kepada Allah, ia boleh menghilangkan rasa sakit dan derita sebagaimana seseorang yang berperang tidak akan merasakan sakit terluka tubuhnya melainkan ia disibukkan dengan peperangan. Seseorang yang hatinya sibuk kepada kecintaan kepada kerinduan kepada Allah tidak akan merasakan sakit atas ujian dan musibah yang ditakdirkan Allah kepada dirinya, ataupun ia merasakan sakit namun sakitnya berkurang dengan kecintaannya kepada Allah, jika cinta kepada sesuatu dapat dilihat dengan indera boleh bertambah kuat, begitu juga cinta dengan mendapat penglihatan basirah.

\section{i) Takwa dan Wara'}

Said Hawwa menyamakan maksud wara dengan takwa, manakala Imam Imam Al-Ghazali berpendapat takwa lebih tinggi daripada wara'. Perkara yang paling ditekankan dalam memahami takwa adalah tanggungjawab menunaikan fardhu kifayah dengan tidak meninggalkan ibadah khususnya penerapan maqam ihsan. Sentiasa melakukan perkara kebaikan dan menghindari kemaksiatan. Manakala perbahasan wara' sebagaimana pandangan imam ghazali mempunyai tingkatantingkatan. Pertama, wara' al'udul, meninggalkan semua perkara haram yang telah difatwakan haram. Kedua, meninggalkan perkara syubhah yang tidak wajib ditinggalkan namun disunatkan. Ketiga, wara' al-Muttaqin, iaitu meninggalkan sesuatu walaupun perkara tersebut halal kerana takut terambil sesuatu larangan dan jatuh kepada yang haram. Abu Darda' berkata : 'Salah satu tanda kesempurnaan takwa adalah seseorang yang menjaga dirinya walaupun terhadap perkara yang kecil sehingga ia meninggalkan sesuatu yang halal kerana takut terjatuh kepada yang haram". Keempat, wara' al-Siddiqin adalah warak terhadap perkara yang jelas kehalalannya. Halal yang dimaksudkan adalah perkara yang tidak menyebabkan seseorang jatuh kepada perbuatan maksiat atau dapat membantunya jatuh kepada maksiat.

\section{j) Syukur}

Takwa adalah jalan menuju syukur, manakala syukur adalah maqam yang lebih tinggi daripada taqwa sebagaimana firman Allah :

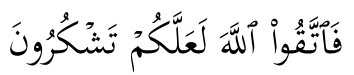

Artinya: "Kerana itu bertakwalah kepada Allah supaya kamu mensyukuriNya"

Allah menyebutkan syukur diiringi dengan perintah berzikir sedangkan berzikir adalah ibadah yang mulia sebagaimana firman Allah yang maksudnya: "Dan sesunggubnya mengingati Allah itu lebih besar (keutamaannya) dari ibadah-ibadah yang lain" (Al-Ankabut:45). Orang-orang yang selalu bersyukur juga adalah orang-orang pilihan, berikutan firman Allah "Dan sedikit sekali dari hambabambaku yang berterima kasib" (surah saba:13).

k) Muraqabah dan Musyahadah 
Asas daripada prinsip ini adalah ihsan, berdasarkan hadis sahih yang artinya, "Kamu beribadah kepada Allah seolab-olab kamu melihatnya, jika kamu tidak. melibatNya maka sesunggubnya ia melibat kamu."

Muraqabah adalah merasakan bahawa Allah SWT memerhatikan kita, sedangkan musyahadah adalah beribadah seakan-akan melihat Allah. Apabila maqam ini telah dicapai maka seseorang itu telah mencapai kejayaan dalam menuju Allah, namun jika belum temui, setiap manusia haruslah berusaha untuk mencapainya. Tanda hidupnya hati adalah dengan merasakan Allah melihat dan mendengar apa yang dibicarakan walaupun di dalam hati. Tanda ketajaman hati adalah apabila dapat menembus apa yang ada di dunia ini dan seakan-akan menyaksikan Allah, maqam ini tidak meungkin akan diperoleh apabila hati mempunyai penyakit kerana penyakit hati akan menhadang cahaya ilahi masuk ke dalam hati. Maqam ini juga tidak akan diperoleh kecuali dengan memperbanyak zikrullah dan memperbanyak taubat kepada Allah.

Jadual Kaedah Tahaqquq dalam Tazkiyah al-Nafs

\begin{tabular}{|l|l|}
\hline Peringkat & Proses/Tindakan \\
\hline \multirow{5}{*}{ Tahaqquq } & Tauhid \\
\cline { 2 - 2 } & Ikhlas \\
\cline { 2 - 2 } & Siddiq \\
\cline { 2 - 2 } & Zuhud \\
\cline { 2 - 2 } & Tawakkal \\
\cline { 2 - 2 } & Mahabbatullah \\
\cline { 2 - 2 } & Khawf, raja' \\
\cline { 2 - 2 } & Taqwa, wara' \\
\cline { 2 - 2 } & Syukur \\
\cline { 2 - 2 } & Sabra \& redha \\
\cline { 2 - 2 } & $\begin{array}{l}\text { Muraqabah \& } \\
\text { musyahadah }\end{array}$ \\
\hline
\end{tabular}

\section{Model Tahaqquq Tazkiyah al-Nafs oleh Said Hawwa}

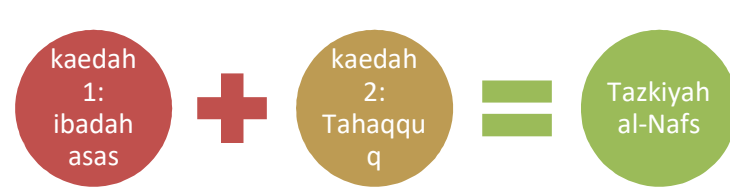

Rajah 2: Model Komprehensif

Tahaqquq Tazkiyah al-Nafs Oleh Said Hawwa (2016).

\section{PENUTUP}

Pendekatan Tazkiyah al-Nafs yang dibawa oleh Sheikh Said Hawwa adalah amat penting dalam kehidupan manusia yang mahu mencari kesejahteraan hidup di dunia mahupun akhirat. Tazkiyah tidak bermaksud menolak perkembangan kehidupan semasa tetapi mengawal kerkembangan hatinya. Tazkiyah al-Nafs membentuk jiwa manusia yang sebenar dengan melakukan segala yang disyariatkan oleh Islam secara istiqamah dengan bimbingan seorang murabbi. Hati dibersihkan daripada sifat yang tercela dan dihias pula dengan sifat yang indah. Tazkiyah perlu melalui pelbagai kaedah di samping hidayah dan taufiq daripada Allah. Hanya manusia yang hatinya suci sahajalah yang dapat kembali kepada Allah dengan sejahtera. Hal ini, merujuk kepada matlamat akhir kaedah dan pendekatan ini adalah menjadi insan yang soleh yang mempunyai kekuatan dalaman (iaitu roh) hasil daripada amalan dan ibadah. Inilah antara rahsia kegemilangan generasi para Sahabat r.a. Umat Islam mesti mengutamakan iman dari nafsu, mempunyai ilmu pengetahuan yang boleh digunapakai dalam semua aspek kehidupan, mengamalkan akhlak-akhlak yang mulia, menjadi "hamba" Allah S.W.T. yang sebenar. Proses penyucian jiwa ini akan menghasilkan ketenteraman, ketenangan dan rasa dekat kepada Allah dengan cara menyucikan hati daripada segala kekotoran dan penyakit dengan membersihkan jiwa dari berbagai jenis 
penyakit akan secara langsung mendekatkan diri seseorang kepada Allah.

\section{PENGHARGAAN}

Kajian ini merupakan kajian yang dibiayai Geran Penyelidikan (Tier 1 Grant) Vot. No. H078 oleh Pusat Penyelidikan, Inovasi, Pengkomersialan \& Pengurusan Konsultasi (ORICC), Universiti Tun Hussein Onn Malaysia.[]

\section{DAFTAR PUSTAKA}

Alfian, Ryan, 'Konsep Kepemimpinan Menurut Sa' îd Hawwa Dalam Kitab Al-Asâs Fî al-Tafsîr Dan alIslâm', 2014

Azra, Azyumardi, 'Ensiklopedi Tasawuf, Bandung: Angkasa, 2008

Baderun, Mawaddah, and Haziyah Hussin, 'Sheikh Sa'id Hawwa: Latar Belakang \& Ketokohan Di Dalam Bidang Pendidikan Islam', Al-Hikmah, 8.1 (2016), 19-35

Hawwa, Said, Al-Mustakblas Fi Tarkiyah al-Anfus (Dar al-Salam: Robbani Press, 1996)

Mohamad, Abu Dardaa, Salasiah Hanin Hamjah, and Ahmad Irdha Mokhtar, 'Konsep Tazkiyah alNafs Menurut al-Harith bin Asad al-Muhasibi', 4 (2017), 11

Noordin, Zidni Nuran, and Zaizul Ab. Rahman, 'Perbandingan Proses Tazkiyah Al-Nafs Menurut Imam al-Ghazali Dan Ibnu Qayyim', Jurnal Al-Turath, 02.01 (2017), 37 46

Suriansah, Dedi, 'Pemikiran Sa'id Hawwa Tentang Jiwa (Studi Analisis Perjalanan Jiwa Menuju Allah)', 2012
Zaini, Nor Azlinah, and Che Zarrina Sa'ari, 'Terapi Spiritual Melalui Kaedah Tazkiyah al-Nafs oleh Syeikh Abdul Qadir al-Mandili dalam Kitab Penawar Bagi Hati', Jurnal Akidah \& Pemikiran Islam, 2016, 35-72 $<$ https://doi.org/10.22452/afkar .sp2016no1.2>

Zaman, Moh, 'Konsep Tazkiyat Al-Nafs Dalam Al-Qur'an: Perspektif Ahmad Mustofa Al-Maraghi Dalam Tafsir Al-Maraghi, Dan Signifikansinya Terhadap Pendidikan Karakter Di Indonesia' (Universitas Islam Negeri Maulana Malik Ibrahim, 2016) 